\title{
Assessment of the Antibacterial Activity of Calcium Hydroxide Combined with Chlorhexidine Paste and Other Intracanal Medications against Bacterial Pathogens
}

Cláudia Fernandes de Magalhães Silveira ${ }^{a}$

Rodrigo Sanches Cunhab

Carlos Eduardo Fontana ${ }^{a}$

Alexandre Sigrist de Martin ${ }^{a}$

Brenda Paula Figueiredo de Almeida Gomes ${ }^{c}$

Rogério Heládio Lopes Mottad

Carlos Eduardo da Silveira Bueno ${ }^{a}$

\section{ABSTRACT}

Objectives: The purpose of this study was to assess the in vitro antibacterial activity of four formulations of calcium hydroxide $\left[\mathrm{Ca}(\mathrm{OH})_{2}\right]$ pastes against Enterococcus faecalis, Staphylococcus aureus, Pseudomonas aeruginosa and Streptococcus mutans.

Methods: A broth dilution test was performed, and the lengths of time for different pastes to kill the microbial cells were recorded and statistically analyzed. The following medications were assessed: Group I - $\mathrm{Ca}(\mathrm{OH})_{2}+2.0 \%$ chlorhexidine $(\mathrm{CHX})$ gel; Group II - $\mathrm{Ca}(\mathrm{OH})_{2}+$ camphorated paramonochlorophenol (CMCP) and propylene glycol; Group III - $\mathrm{Ca}(\mathrm{OH})_{2}+$ propylene glycol; Group IV - Ca(OH) ${ }_{2}+$ saline.

Results: The results showed that E. faecalis was the most resistant microorganism. Groups II and III eliminated all the microbial cells in 15 seconds. Group I took 45 seconds to eliminate E. faecalis.

Conclusions: Under the conditions of this study, it was concluded that all the intracanal medications tested showed antibacterial activity. However, the association of $\mathrm{Ca}(\mathrm{OH})_{2}$ and $\mathrm{PMCC}$ or $\mathrm{Ca}(\mathrm{OH})_{2}$ and propylene glycol showed a better performance, since Groups II and III took a shorter length of time than the other groups to eliminate S. aureus and E. faecalis. (Eur J Dent 2011;5:1-7)

Key words: Calcium hydroxide; Chlorhexidine gel; Intracanal medications; Enterococcus faecalis.

a São Leopoldo Mandic Dental School, Department of Endodontics.

b Catholic University of Campinas, Department of Endodontics.

University of Campinas, Piracicaba Dental School, Department of Endodontics.

d São Leopoldo Mandic Dental School, Department of Anesthesiology and Pharmacology.
Corresponding author:

Cláudia Fernandes de Magalhães Silveira

Rua Pilar do Sul, 429 -

Chácara da Barra

Campinas - São Paulo,

Brazil ZIP 13090-757

Phone: (05519) 32554321

E-mail: claudinhasilvedagmail.com 


\section{INTRODUCTION}

The success of root canal treatment depends on mechanical preparation, irrigation, microbial control and complete filling of the root canal system. ${ }^{1,2}$ Bacteria and their products are considered the primary etiologic agents of pulp necrosis and perirradicular lesions. Microorganisms infecting the root canal may survive endodontic procedures, ${ }^{2-4}$ due to anatomical complexities and consequent limitations of access by instruments and irrigants. ${ }^{5}$

Microorganisms may also infiltrate through a poor temporary seal during the period between appointments for endodontic treatment. ${ }^{6}$ Therefore, the use of a root canal dressing is important for obtaining ${ }^{7}$ and maintaining a disinfected canal after mechanical instrumentation and before root canal obturation. 2,8,9 Despite its viscous consistency, the paste made by mixing calcium hydroxide $\left[\mathrm{Ca}(\mathrm{OH})_{2}\right]$ and chlorhexidine $(\mathrm{CHX})$ gel $2 \%$ was found not to influence the sealing ability of the obturation technique. ${ }^{10}$

Calcium hydroxide plays an important role in endodontics due to its ability to induce hard tissue formation, ${ }^{11}$ its antibacterial effect ${ }^{12}$ and its ability to act as a physical barrier to prevent root canal reinfection. ${ }^{13}$ In an attempt to enhance the antimicrobial activity of $\mathrm{Ca}(\mathrm{OH})_{2}$, different substances have been used as vehicles. The combination of $\mathrm{Ca}(\mathrm{OH})_{2}$ and camphorated paramonochlorophenol (CMCP) was proposed by Frank ${ }^{14}$ to extend the antibacterial spectrum of $\mathrm{Ca}(\mathrm{OH})_{2}$, mainly against some facultative or anaerobic bacteria. However, previous studies have clearly shown the toxicity of CMCP in vivo and in vitro. ${ }^{15}$ Therefore, the use of these phenolic compounds should be treated with caution in dentistry. ${ }^{15}$

Chlorhexidine gluconate has been widely used as an endodontic irrigant, because of its antimicrobial activity against Gram-positive and Gramnegative microorganisms. ${ }^{16-19}$ Chlorhexidine gluconate may also present residual antimicrobial activity on the dentin surface after prolonged contact (at least one week) with the root canal. ${ }^{20-22}$

Recent studies have suggested that $\mathrm{CHX}$ could be used in combination with $\mathrm{Ca}(\mathrm{OH})_{2}$ to improve antimicrobial efficacy against $\mathrm{Ca}(\mathrm{OH})_{2}$-resistant microorganisms. $4,17,19,23-25$

The broth dilution test has been used to investigate the in vitro antimicrobial activity of $\mathrm{CHX}$ (in gel and liquid formulations) and sodium hypochlorite against several endodontic pathogens. ${ }^{26-31}$ The agar diffusion method only indicates the medicament potential to eliminate bacteria within the root canal system, ${ }^{30}$ but does not quantify its action timing. Unlike the agar diffusion method, the broth dilution test is not dependent on the solubility and diffusibility of the substance evaluated in the culture medium.

The purpose of this study was to assess the in vitro antimicrobial effect of $\mathrm{Ca}(\mathrm{OH})_{2}$ when combined with saline, propylene glycol, CMCP plus propylene glycol and $2 \% \mathrm{CHX}$ gel against $S$. aureus, $S$. mutans, E. faecalis and P. aeruginosa.

\section{MATERIALS AND METHODS}

The methodology of this study was adapted from Vianna et $\mathrm{al}^{26}$ and Gomes et al, ${ }^{29}$ who used a broth dilution test to quantify the time required for an antimicrobial agent to inhibit microbial growth.

$\mathrm{Ca}(\mathrm{OH})_{2}$ pastes were prepared using $\mathrm{Ca}(\mathrm{OH})_{2}$ P.A. (Biodinâmica, Ibiporã, PR, Brazil) combined with different vehicles, as follows: Group I - $\mathrm{Ca}(\mathrm{OH})_{2}+2.0 \% \mathrm{CHX}$ (Endogel, Itapetininga, SP, Brazil); Group II - $\mathrm{Ca}(\mathrm{OH})_{2}+\mathrm{CMCP}$ (Biodinâmica, Ibiporã, PR, Brazil) + propylene glycol (SIAFARMA, Campinas, SP, Brazil); Group III - $\mathrm{Ca}(\mathrm{OH})_{2}+$ propylene glycol; Group IV - $\mathrm{Ca}(\mathrm{OH})_{2}$ + saline (Ecibra, Santo Amaro, SP, Brazil). The $\mathrm{Ca}(\mathrm{OH})_{2}$ pastes were prepared in a proportion of 2:1 or 2:1:2 (group II) and the consistency was similar to that of a toothpaste. Saline was used as a negative control. Antibacterial activity was evaluated against the Grampositive microorganisms E. faecalis (ATCC 29212), S. aureus (ATCC 25923), S. mutans (UA 159) and $P$. aeruginosa (ATCC 27853). The strains were inoculated into brain-heart infusion (BHI) broth and incubated in an aerobic atmosphere at $37^{\circ} \mathrm{C}$. After 24 hours, the turbidity of the culture medium was assessed using a spectrophotometer (Ultrospec 1000; Amersham Pharmacia Biotech, Cambridge, UK).

For the broth dilution test, $10 \mu$ of each tested substance, as well as sterile saline (control group), were placed in 24-well cell culture plates (ref. no. 3524, vol. $3.2 \mathrm{~mL}$; Corning, NY, USA). Thus, $20 \mu \mathrm{l}$ of the microbial suspension were added to each well containing the substances or the control solution. Six wells were used for each time period and medication (i.e. from each well, only one time 
period and medication were tested). Overall, 1080 wells were used, comprising 864 for all the test groups and 216 for the control group.

The well cell culture plates were placed onto an upside down $250 \mathrm{~mL}$ stainless steel griffin beaker (BK 1122, MGL Scientific, Elko, NV, USA) inside an ultrasonic cleaner (Bransonic Ultrasonics Corporation, Danbury, CT, USA) that had been previously filled with $1400 \mathrm{~mL}$ of distilled water up to the operating level. These plates were ultrasonicated for $10 \mathrm{~s}$ and left to stand for different periods of time: 15, 30, 45, 60 seconds, 5, 15, 30 minutes, 1 and 24 hours. After each period of time, $10 \mu \mathrm{l}$ from each well was transferred to a tube containing 2 $\mathrm{mL}$ of fresh broth media (BHI), containing neutralizers in order to prevent continued action of the substances.

The neutralizer for $\mathrm{CHX}$ was Tween 80 plus $0.07 \%$ lecithin, whereas citric acid was used for $\mathrm{Ca}(\mathrm{OH})_{2}{ }^{26}$ All tubes were left at $37^{\circ} \mathrm{C}$ for 48 hours under appropriate gaseous conditions. After this period, $10 \mu \mathrm{l}$ from each tube were inoculated onto agar plates to evaluate bacterial growth. The purity of the positive cultures was confirmed by Gram staining, biochemical tests and analysis of the colony morphology on blood agar plates. The time needed for each substance to achieve complete inhibition of microbial growth was recorded and transformed into seconds.

\section{RESULTS}

Figure 1 presents the period of contact required for the 4 groups to produce negative cultures of all tested microorganisms. Groups II and III eliminated all the microorganisms in 15 seconds. Only 15 seconds were needed for the $\mathrm{Ca}(\mathrm{OH})_{2}+2.0 \% \mathrm{CHX}$ combination to produce negative cultures of $S$. mutans and P. aeruginosa. However, this group took 45

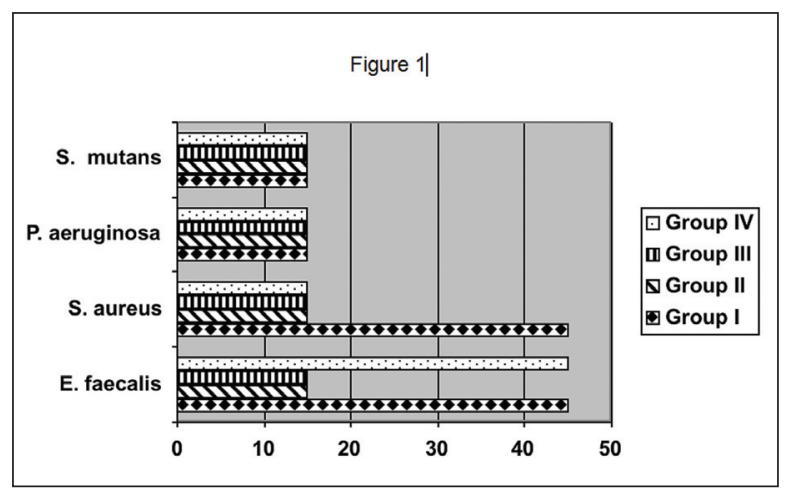

Figure 1. Maximum time (in seconds) needed for all the test substances to produce negative cultures of each microorganism. seconds to eliminate $S$. aureus and E. faecalis. The same time, 45 seconds, was needed for the substances of Group IV to produce negative cultures of E.faecalis.

According to the present study, the microbial resistance to all substances tested can be ranked from the strongest to the weakest as follows: $E$ faecalis was the strongest, followed by $S$. aureus, $P$. aeruginosa and $S$. mutans (the latter two at the same levell.

\section{DISCUSSION}

Establishing the spectrum of activity of any antimicrobial agent is essential for improving infection control. ${ }^{27}$ The in vitro techniques that have been used for this purpose have advantages and disadvantages. The agar diffusion method may not express the full potential of the test substance, since the inhibition zones depend on its solubility and diffusibility in the culture medium. ${ }^{9,28}$ In the present study, the broth dilution test was used, which relies on direct and close contact between the test microorganism and materials. ${ }^{32}$ It is considered a more precise method to analyze medications than the agar diffusion, in which the medicaments dissociate and diffuse differently through the media. ${ }^{28}$ In summary, the broth dilution test uses a liquid culture medium and allows liquid and paste formulations to have a more similar diffusion conditions than the agar diffusion method.

There are several reasons for a poorer in vivo performance of medicaments as compared with their in vitro results, including poor penetration of the medicament/irrigants, low concentration, short exposure time, small overall volume, poor exchange of irrigants in the apical portion of the root canal, and inactivation of the medicament in the root canal. Resistant, surviving microbes can be isolated even on the walls of the main root canal after cleaning and shaping procedures. The results of this study showed strong activity of the substances tested when in direct contact with microorganisms. However, $\mathrm{Ca}(\mathrm{OH})_{2}$, in combination with CMCP and/or propylene glycol, mixed very well with the bacterial suspension, and immediately exerted its antimicrobial action, whereas the gel formulation, which did not mix as easily, delayed required direct contact between bacterial cells and $\mathrm{CHX}$, thus requiring a longer time to act against E. faecalis and S.aureus. 
Calcium hydroxide is the recommended intracanal medication for the treatment of apical periodontitis. Its antimicrobial action mechanism is influenced by the speed of its dissociation into calcium ions and hydroxyl ions ${ }^{23}$ and by inactivating enzymes of the cytoplasmic membrane of microorganisms, thus causing toxic effects on the bacterial cells. ${ }^{27}$ To be effective against the bacteria located inside dentinal tubules, the hydroxyl ions must diffuse at sufficient concentrations and exceed the dentin buffering ability, thus producing $\mathrm{pH}$ levels high enough to destroy or inactivate microorganisms. ${ }^{33}$ Another mechanism of action of this medication is its ability to absorb carbon dioxide, thus leading to the death of $\mathrm{CO}_{2}$-dependent bacteria, such as Actinomyces. ${ }^{34}$

Different vehicles have been added to $\mathrm{Ca}(\mathrm{OH})_{2}$ in an attempt to enhance its antimicrobial activity, dissociation and biocompatibility. ${ }^{21,23,25,27,33,35,36}$ The combination of $\mathrm{Ca}(\mathrm{OH})_{2}$ with $\mathrm{CMCP}$ has previously been shown to be more capable of inhibiting the growth of bacteria than $\mathrm{CHX}$ and $\mathrm{Ca}(\mathrm{OH})_{2}$ combined with sterile saline. ${ }^{37}$ Chang et $\mathrm{al}^{15}$ demonstrated that CMCP is cytotoxic to the target periodontal ligament cells by inhibiting cell viability and proliferation. The present study found that this association kills microorganisms in 15 seconds.

Propylene glycol is a clear, colorless, and odorless liquid with a characteristic taste that resembles that of glycerin. Its wide application in endodontics as a vehicle for intracanal medicaments is attributable to its strong antibacterial action against microorganisms commonly found in infected root canals. ${ }^{38}$ Another advantage of this substance is its consistency, which improves the handling qualities of the paste. ${ }^{12}$ According to Simon et $\mathrm{al}^{39}$ by the use of this vehicle it is possible to control the level of $\mathrm{pH}$ rise and $\mathrm{Ca}^{2+}$ release that can be sustained for a long period. The authors also stated that there is no justification to continue the use of CMCP as a vehicle for $\mathrm{Ca}(\mathrm{OH})_{2}$. Instead propylene glycol that possesses many desirable qualities can be routinely used in preference to all the other vehicles. The effects of glycerine and propylene glycol mixing vehicles on the $\mathrm{pH}$ of $\mathrm{Ca}(\mathrm{OH})_{2}$ preparations was investigated using conductivity testing by Safavi et al..$^{40} \mathrm{~A}$ range of 10-30 percent for a glycerine/water mixture and 10-40 percent for a propylene glycol/water mixture resulted in the greatest amount of conductiv- ity. In our study, only 15 seconds were needed for $\mathrm{Ca}(\mathrm{OH})_{2}$ combined with propylene glycol to kill all microorganisms.

Chlorhexidine gluconate is a broad-spectrum antibacterial agent whose positively charged molecules can be adsorbed onto dentin and prevent microbial colonization on the dentin surface. ${ }^{2,41}$ Ferguson et $\mathrm{al}^{42}$ showed that chlorhexidine diffuses through the root canal, and possibly into the dentinal tubules, thus being an effective anticandidal agent. Interestingly, $\mathrm{Ca}(\mathrm{OH})_{2}$ has been shown to be inefficient in the killing of both facultative anaerobes and yeasts. ${ }^{43}$ The aim of combining $\mathrm{Ca}(\mathrm{OH})_{2}$ and $2 \% \mathrm{CHX}$ gel (CG) is to enhance antimicrobial effectiveness, particularly against resistant microorganisms such as $E$. faecalis that are implicated in the failure of root canal treatment. ${ }^{44,45}$ The association of $\mathrm{CHX}$ and $\mathrm{Ca}(\mathrm{OH})_{2}$ has been tested against $E$. faecalis in infected bovine root dentine, demonstrating that the combined medicaments were effective..$^{46,47}$

Enterococcus faecalis are enteric facultative anaerobic Gram-positive cocci that have been associated with persistent endodontic infections. ${ }^{48}$ A distinguishing characteristic of E. faecalis is its ability to grow at an alkaline $\mathrm{pH}$ that normally inhibits other bacteria. Evans et $\mathrm{al}^{49}$ found that a functioning intracellular proton pump was the primary factor triggering alkaline resistance of $E$. faecalis, because it can maintain $\mathrm{pH}$ homeostasis within a narrow physiological range, allowing enzymes to work normally. ${ }^{50}$

The direct contact method revealed that the combination of $\mathrm{Ca}(\mathrm{OH})_{2}$ and PMCC was more effective than the combination of $\mathrm{Ca}(\mathrm{OH})_{2}$ and $\mathrm{CHX}$, since Group I took 45 seconds to produce negative cultures for $S$. aureus and E. faecalis. As previously mentioned, the results of this method can be justified by the high viscosity of the $\mathrm{CHX}$ gel, which may impair direct contact between the medication and microorganism. Estrela et al ${ }^{27}$ demonstrated that the lower the viscosity of the vehicle, the higher the ionic dissociation of the $\mathrm{Ca}(\mathrm{OH})_{2}$. Athanassiadis et al $^{51}$ reported that the reduced antibacterial activity of $\mathrm{Ca}(\mathrm{OH})_{2}$ and $\mathrm{CHX}$ association may be because chlorhexidine is a cationic biguanide whose optimal antimicrobial activity is achieved within a $\mathrm{pH}$ range of 5.5-7.0. Therefore, it is likely that alkalinizing the $\mathrm{pH}$ by adding $\mathrm{Ca}(\mathrm{OH})_{2}$ to $\mathrm{CHX}$ will lead to precipitation of the $\mathrm{CHX}$ mol- 
ecules and thereby decreases its effectiveness. In a study using agar diffusion, Haenni et al ${ }^{52}$ could not demonstrate any additive antibacterial effect by mixing $\mathrm{Ca}(\mathrm{OH})_{2}$ powder with $\mathrm{CHX}(0.5$ percent). In fact, they showed that the $\mathrm{CHX}$ had a reduced antibacterial action. However, $\mathrm{Ca}(\mathrm{OH})_{2}$ did not lose its antibacterial properties in such a mixture. This may be due to the deprotonation of $\mathrm{CHX}$ at a pH greater than 10 , which reduces its solubility and alters its interaction with bacterial surfaces as a result of the altered charge of the molecule. Mohammadi \& $\mathrm{Abbott}^{53}$ provided a systematic review regarding different aspects of $\mathrm{CHX}$ of relevance to endodontics, concluding that the usefulness of mixing $\mathrm{Ca}(\mathrm{OH})_{2}$ with $\mathrm{CHX}$ still remains unclear and controversial.

\section{CONCLUSIONS}

Based on the results of this research, it can be concluded that all the intracanal medications tested showed antibacterial activity. However, the association of $\mathrm{Ca}(\mathrm{OH})_{2}$ and PMCC or $\mathrm{Ca}(\mathrm{OH})_{2}$ and propylene glycol showed a better performance, once Groups II and III took a shorter length of time than the other groups to eliminate $S$. aureus and $E$. faecalis.

\section{REFERENCES}

1. Vahdaty A, Pitt Ford TR, Wilson RF. Efficacy of chlorhexidine in disinfecting dentinal tubules in vitro. Endod Dent Traumatol 1993;9:243-248.

2. El Karim I, Kennedy J, Hussey D. The antimicrobial effects of root canal irrigation and medication. Oral Surg Oral Med Oral Pathol Oral Radiol Endod 2007;103:560-569.

3. Bystrom A, Sundqvist G. Bacteriologic evaluation of the effect of 0.5 percent sodium hypochlorite in endodontic therapy. Oral Surg Oral Med Oral Pathol 1983;55:307-312.

4. Zerella JA, Fouad AF, Spangberg LSW, Effectiveness of a calcium hydroxide and chlorhexidine digluconate mixture as disinfectant during retreatment of failed endodontic cases. Oral Surg Oral Med Oral Pathol Oral Radiol Endod 2005;100:756-761.

5. Haapasalo M, Qian W, Portenier I, Waltimo T. Effects of dentin on the antimicrobial properties of endodontic medicaments. J Endod 2007;33:917-925.

6. Friedman S, Komorowski R, Maillet W, Klimaite R, Nguyen $H Q$, Torneck CD. In vivo resistance of coronally induced bacterial ingress by an experimental glass ionomer cement root canal sealer. $J$ Endod 2000;26:1-5.
7. De Rossi A, Silva LAB, Leonardo MR, Rocha LB, Rossi MA. Effect of rotary or manual instrumentation, with or without a calcium hydroxide/1\% chlorhexidine intracanal dressing, on the healing of experimentally induced chronic periapical lesions. Oral Surg Oral Med Oral Pathol Oral Radiol Endod 2005;99:628-636.

8. Chong BS, Pitt Ford TR. The role of intracanal medication in root canal treatment. Int Endod J 1992;25:97-106.

9. Basrani B, Tjaderhane L, Santos M, Pascon E, Grad H, Lawrence $H P$, and Friedman S, Efficacy of chlorhexidine- and calcium hydroxide-containing medicaments against Enterococcus faecalis in vitro. Oral Surg Oral Med Oral Pathol Oral Radiol Endod 2003;96:618-624.

10. Kontakiotis EG, Tsatsoulis IN, Papanakou SI, Tzanetakis GN. Effect of $2 \%$ chlorhexidine gel mixed with calcium hydroxide as an intracanal medication on sealing ability of permanent root canal filling: a 6-month follow-up. J Endod 2008;34:866-870.

11. Sathorn C, Parashos P, Messer H. Antibacterial efficacy of calcium hydroxide intracanal dressing: a systematic review and meta-analysis. Int Endod J 2007;40:2-10.

12. Pacios MG, de la Casa ML, de los Angeles Bulacio M, López ME. Calcium hydroxide's association with different vehicles: In vitro action on some dentinal components. Oral Surg Oral Med Oral Pathol Oral Radiol Endod 2003;96:96101.

13. Ferreira FB, Torres SA, Rosa OP, Ferreira CM, Garcia RB, Marcucci MC, Gomes BP. Antimicrobial effect of propolis and other substances against selected endodontic pathogens. Oral Surg Oral Med Oral Pathol Oral Radiol Endod 2007;104:709-716.

14. Frank AL. Therapy for the divergent pulpless tooth by continued apical formation. J Am Dent Assoc 1966;72:87-93.

15. Chang YC, Tai KW, Chou LS, Chou MY. Effects of camphorated parachlorophenol on human periodontal ligament cells in vitro. J Endod 1999;25:779-781.

16. Gomes BP, Ferraz CC, Vianna ME, Berber VB, Teixeira FB, Souza-Filho FJ. In vitro antimicrobial activity of several concentrations of sodium hypochlorite and chlorhexidine gluconate in the elimination of Enterococcus faecalis. Int Endod J 2001;34:424-428.

17. Gomes BP, Sato E, Ferraz CC, Teixeira FB, Zaia AA, SouzaFilho FJ. Evaluation of time required for recontamination of coronally sealed canals medicated with calcium hydroxide and chlorhexidine. Int Endod J 2003;36:604-609.

18. Davis JM, Maki J, Bahcall JK. An in vitro comparison of the antimicrobial effects of various endodontic medicaments on Enterococcus faecalis. J Endod 2007;33:567-569. 
19. Neelakantan P, Sanjeev K, Subbarao CV. Duration-dependent susceptibility of endodontic pathogens to calcium hydroxide and chlorhexidine gel used as intracanal medicament: an in vitro evaluation. Oral Surg Oral Med Oral Pathol Oral Radiol Endod 2007;104:e138-141.

20. Basrani B, Ghanem A, Tjäderhane L. Physical and chemical properties of chlorhexidine and calcium hydroxidecontaining medications. J Endod 2004;30:413-417.

21. Ercan E, Dalli M, Dülgergil CT. In vitro assessment of the effectiveness of chlorhexidine gel and calcium hydroxide paste with chlorhexidine against Enterococcus faecalis and Candida albicans. Oral Surg Oral Med Oral Pathol Oral Radiol Endod 2006;102:e27-31.

22. Lee $\mathrm{Y}, \mathrm{Han} \mathrm{SH}, \mathrm{Hong} \mathrm{SH}$. Antimicrobial efficacy of a polymeric chlorhexidine release device using in vitro model of Enterococcus faecalis dentinal tubule infection. $J$ Endod 2008;34:855-858.

23. Zehnder M, Grawehr M, Hasselgren G, Waltimo T. Tissuedissolution capacity and dentin-disinfecting potential of calcium hydroxide mixed with irrigating solutions. Oral Surg Oral Med Oral Pathol Oral Radiol Endod 2003;96:608613.

24. Sirén EK, Haapasalo MP, Waltimo TM, Ørstavik D. In vitro antibacterial effect of calcium hydroxide combined with chlorhexidine or iodine potassium iodide on Enterococcus faecalis. Eur J Oral Sci 2004;112:326-331.

25. Siqueira JF Jr, Paiva SS, Rocas IN. Reduction in the cultivable bacterial populations in infected root canals by a chlorhexidine-based antimicrobial protocol. J Endod 2007;33:541-547.

26. Vianna ME, Gomes BP, Berber VB, Zaia AA, Ferraz CC, de Souza-Filho FJ. In vitro evaluation of the antimicrobial activity of chlorhexidine and sodium hypochlorite. Oral Surg Oral Med Oral Pathol Oral Radiol Endod 2004;97:79-84.

27. Estrela C, Rodrigues de Araújo Estrela C, Bammann LL, Pecora JD. Two methods to evaluate the antimicrobial action of calcium hydroxide paste. J Endod 2001;27:720-723.

28. Gomes BPFA, Vianna ME, Sena NT, Zaia AA, Ferraz, Souza Filho FFS. In vitro evaluation of the antimicrobial activity of calcium hydroxide combined with chlorhexidine gel used as intracanal medicament. Oral Surg Oral Med Oral Pathol Oral Radiol Endod 2006;102:544-550.

29. Gomes BPFA, Ferraz CCR, Vianna ME, Berber VB, Teixeira FB, Souza-Filho FJ. In vitro antimicrobial activity of several concentrations of sodium hypochlorite and chlorhexidine gluconate in the elimination of Enterococcus faecalis. Int Endod J 2001;34:424-428.
30. Vianna ME, Gomes BP, Sena NT, Zaia AA, Ferraz CC, de Souza Filho FJ. In vitro evaluation of the susceptibility of endodontic pathogens to calcium hydroxide combined with different vehicles. Braz Dent J 2005;16:175-180.

31. Vianna ME, Gomes BP. Efficacy of sodium hypochlorite combined with chlorhexidine against Enterococcus faecalis in vitro. Oral Surg Oral Med Oral Pathol Oral Radiol Endod. 2009;107:585-589.

32. Gomes BP, Ferraz CC, Vianna ME, Rosalen PL, Zaia AA, Teixeira FB, Souza-Filho FJ. In vitro antimicrobial activity of calcium hydroxide pastes and their vehicles against selected microorganisms. Braz Dent J 2002;13:155-161.

33. Weiss El, Shalhav M, Fuss Z. Assessment of antibacterial activity of endodontic sealers by a direct contact test. Endod Dent Traumatol 1996;12:179-184.

34. Estrela C, Estrela CRA, Moura J, Bammann LL. Testing calcium hydroxide antimicrobial potential by different methods. J Dent Res 2000;79:529.

35. Yücel AC, Aksoy A, Ertas E, Güvenç D. The pH changes of calcium hydroxide mixed with six different vehicles. Oral Surg Oral Med Oral Pathol Oral Radiol Endod 2007;103:712717.

36. Siqueira JF Jr, de Uzeda M. Intracanal medicaments: evaluation of the antibacterial effects of chlorhexidine, metronidazole, and calcium hydroxide associated with three vehicles. J Endod 1997;23:167-169.

37. Penesis VA, Fitzgerald PI, Fayad MI, Wenckus CS, BeGole EA, Johnson BR. Outcome of one-visit and two-visit endodontic treatment of necrotic teeth with apical periodontitis: a randomized controlled trial with one-year evaluation. J Endod 2008;34:251-257.

38. Fava LR, Saunders WP. Calcium hydroxide pastes: classification and clinical indications. Int Endod J 1999;32:257-282.

39. Simon ST, Bhat KS, Francis R. Effect of four vehicles on the $\mathrm{pH}$ of calcium hydroxide and the release of calcium ion. Oral Surg Oral Med Oral Pathol Oral Radiol Endod 1995;80:459-464

40. Safavi K, Nakayama TA. Influence of mixing vehicle on dissociation of calcium hydroxide in solution. $J$ Endod 2000;26:649-651.

41. Basrani B, Santos JM, Tjäderhane L, Grad H, Gorduysus O, Huang J, Lawrence HP, Friedman S. Substantive antimicrobial activity in chlorhexidine-treated human root dentin. Oral Surg Oral Med Oral Pathol Oral Radiol Endod 2002;94:240-245.

42. Ferguson JW, Hatton JF, Gillespie MJ. Effectiveness of intracanal irrigants and medications against the yeast Candida albicans. $J$ Endod 2002;28:68-71. 
43. Waltimo TM, Sirén EK, Orstavik D, Haapasalo MP. Susceptibility of oral Candida species to calcium hydroxide in vitro. Int Endod J 1999;32:94-98.

44. Turk BT, Sen BH, Ozturk T. In vitro antimicrobial activity of calcium hydroxide mixed with different vehicles against Enterococcus faecalis and Candida albicans. Oral Surg Oral Med Oral Pathol Oral Radiol Endod 2009;108:297-301.

45. Gomes BP, Montagner F, Berber VB, Zaia AA, Ferraz CC, de Almeida JF, Souza-Filho FJ. Antimicrobial action of intracanal medicaments on the external root surface. $J$ Dent 2009;37:76-81.

46. Evans MD, Baumgartner JC, Khemaleelakul SU, Xia T. Efficacy of calcium hydroxide: chlorhexidine paste as an intracanal medication in bovine dentin. $J$ Endod 2003;29:338339.

47. Sirén EK, Haapasalo MP, Waltimo TM, Ørstavik D. In vitro antibacterial effect of calcium hydroxide combined with chlorhexidine or iodine potassium iodide on Enterococcus faecalis. Eur J Oral Sci 2004;112:326-331.

48. Sundqvist G, Figdor D, Persson S, Sjögren U. Microbiologic analysis of teeth with failed endodontic treatment and the outcome of conservative re-treatment. Oral Surg Oral Med Oral Pathol Oral Radiol Endod 1998;85:86-93.

49. Evans M, Davies JK, Sundqvist G, Figdor D. Mechanisms involved in the resistance of Enterococcus faecalis to calcium hydroxide. Int Endod J 2002;35:221-228.

50. McHugh CP, Zhang P, Michalek S, Eleazer PD. pH required to kill Enterococcus faecalis in vitro. J Endod 2004;30:218219.

51. Athanassiadis B, Abbott PV, Walsh LJ. The use of calcium hydroxide, antibiotics and biocides as antimicrobial medicaments in endodontics. Aust Dent J 2007;52:S64-82.

52. Haenni S, Schmidlin PR, Mueller B, Sener B, Zehnder M. Chemical and antimicrobial properties of calcium hydroxide mixed with irrigating solutions. Int Endod J 2003;36:100105

53. Mohammadi Z, Abbott PV. The properties and applications of chlorhexidine in endodontics. Int Endod J 2009;42:288302. 